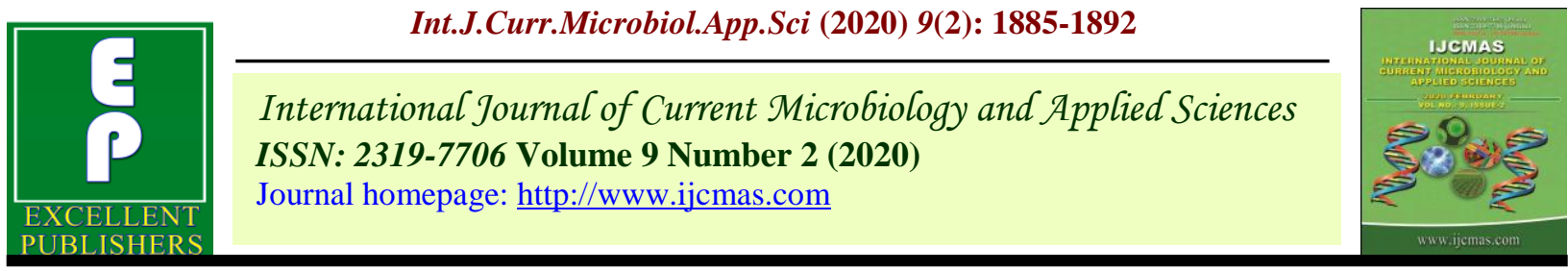

\title{
Effect of Bee Pollination and Attractants on Quantitative and Qualitative Parameters of Onion (Alliun cepa) Seed Yield and Quality
}

\author{
Venkatesh Hosamani $^{1 *}$, Venkateshalu ${ }^{2}$, N. Jagadeesha ${ }^{3}$, M. S. Reddy ${ }^{4}$, \\ P.M Gangadarappa ${ }^{5}$ and B. Ravikumar ${ }^{5}$ \\ ${ }^{1}$ Division of Entomology, College of Horticulture, Munirabad, University of \\ Horticultural Sciences, Bagalkot, Karnataka, India \\ ${ }^{2}$ Division of Entomology, College of Horticulture, Bagalkot, Karnataka, India \\ ${ }^{3}$ Division of Agronomy, College of Horticulture, Munirabad, University of Horticultural \\ Sciences, Bagalkot, Karnataka, India \\ ${ }^{4}$ Maharani Cluster University, Bangalore, Karnataka, India \\ ${ }^{5}$ Division of Horticulture, College of Horticulture, Munirabad, University of Horticultural \\ Sciences, Bagalkot, Karnataka, India \\ *Corresponding author
}

\section{A B S T R A C T}

\section{Keywords}

Pollination, Apis cerana, Attractants, Quantitative and Qualitative Parameters, Onion

Article Info

Accepted:

15 January 2020

Available Online:

10 February 2020
Nearly $75 \%$ of the world's flowering plants are dependent on insects for pollination, with honeybees being well known for their importance for several crops. The Experiment was conducted to know the effect of pollination involving Apis cerana as major component in the study concentrated on onion crop growth. The open pollinated plot sprayed with cacambe (10) was found significantly superior by recording highest number of seeds/umbel (930.44 seeds/umbel) which resulted in 65.92 and 126.40 per cent increase over open pollination without spray and caged plot without bees, respectively. The same treatment found to get the superior test weight ( $4.19 \mathrm{~g} / 1000$ seeds), higher net plot $(4 \mathrm{~m} \mathrm{x} 4 \mathrm{~m})$ yield of 1.42 $\mathrm{kg} / \mathrm{plot}$. In case of qualitative parameters also the cacambe $(10 \%)$ showed the significant result over the other treatments viz., maximum root length of $4.39 \mathrm{~cm}$ and maximum shoot length of $9.92 \mathrm{~cm}$ with an increase of 26.09 and 39.60 per cent over pollinated without spray and caged plot without bees, respectively. The next best treatments was jaggery $(10 \%)(9.86 \mathrm{~cm})$ and Bee-Q $(1.25 \%)(9.79 \mathrm{~cm})$.

\section{Introduction}

Crop pollination is the most important economic outcome of honeybee activities. A well planned managed bee pollination ensures higher yield levels with good quality. Pollination is closely associated with fruit and seed set, yield and seed quality. Nowadays intensive agriculture plays major role in declining native pollinators through the 
modification and elimination of pollinator habitats and non judicious use use of agricultural chemicals (pesticides, herbicides and fertilizers) Kearns et al., 1998 (1). Intensive cultivation of land will destroy many natural food sources and nesting sites of wild pollinating insects. Free (1993) (2).

Onion (Allium cepa L.), cross pollination is common and self pollination can not occur because of protandry and sticky pollen. Large number of insects including the honey bee species like Apis dorsata, A. cerana indica A. florae, Trigona irridipennis, and non Apidae species like solitary bees, flies, butterflies and beetles visit onion flowers both for pollen and nectar. Thirty four insect species of different orders and families were visited the coriander flowers and apoidea was prominent group among all flower visitors. Among these, honey bees play major role in cross pollination of onion crop. Singh and Dharamwal (1970)(3) noted the increase of 21.80 per cent in yield and better seed germination with insect pollination of onion crop. Further, they reported that the open pollinated onion crop showed 72.00 to 79.00 per cent increase in seed set compared to the caged or bagged plants. There was 12 to 300 times more increase in seed set due to insect pollination. Kumar et al. (1989) (4) recorded $90.47 \%$ seed set and $77.8 \%$ germination in bee pollinated onion crop.

Onion crop is being protandrous flowering vegetable crop requires cross pollination and for that it is necessary to increase the bees visits. Any material to increase the honey bee visits to specific crops would be of great practical value to harvest the benefits of cross pollination. Bee pollination not only increases the yield of various vegetables but also improves its quality. Honey bees are efficient and primary pollinators of cross-pollinated crops like onion. Perusal of literature shows that limited information is available on effect of bee pollination on quality of onion seed and hence the present investigation was undertaken.

\section{Materials and Methods}

The effect of managed honeybee pollination on onion seed yield and quality was investigated and Systematic observations were recorded at farmers fields of Benakanakonda village near by Krishi Vigyana Kendra (KVK), Hanumanamatti, Haveri District $\left(14^{0} 17^{\prime}, 15^{0} 01^{\prime \prime}, 75^{0} 35^{\prime \prime}\right.$ to $75^{0} 50$ ', $750 \mathrm{~m} \mathrm{msl}$ ) during 2010-2011. The onion, Arka Kalyan variety was used for study in one acre. The experiment was laid out in Randomized Block Design (RBD) with six treatments, each replicated thrice. The $A$. cerana bee box was placed with cage $(4 \mathrm{~m} \mathrm{x} 4$ $\mathrm{m})$ made out of nylon mesh (1 mm size) $\left(\mathrm{T}_{1}\right)$ and maintained no pollinators inside the cage as the control plot $\left(\mathrm{T}_{2}\right)$.

\section{Treatment Details}

$\mathrm{T}_{1}$ Onion crop caged with one bee box

$\mathrm{T}_{2}$ Onion crop caged without bees and other pollinators (control)

$\mathrm{T}_{3}$ Open pollination with cacambe $(10 \%)$

$\mathrm{T}_{4}$ Open pollination with Bee-Q (1.25\%)

$\mathrm{T}_{5}$ Open pollination with jaggery solution $(10 \%)$

$\mathrm{T}_{6}$ Open pollination (without any treatment)

In $T_{1}$ and $T_{2}$, bees were caged before the start of flowering during night to avoid natural pollinators. Later, all other treatments $\left(T_{3}\right.$ to $\mathrm{T}_{6}$ ) were imposed at 5 per cent flowering of the crop. Spraying was done two times at 15 days intervals. Bee box with back and front entrance was kept in boundary of cage to facilitate the bees to move in and out either inside or outside the cage. The cage was removed after one month flowering was completed. In order to study the role of pollinators particularly bees in increasing the 
yields and quality of onion seeds, the following quantitative and qualitative parameters were recorded for each treatment $(5 \mathrm{~m} \times 5 \mathrm{~m})$. The quantative parameters viz., number of seeds per head, thousand seed weight (test weight) and net plot yield per ha and qualitative parameters like germination percentage, root length and shoot length were recorded. The data pertaining to influence of bee attractants and qualitative and quantitative parameters were subjected to Duncan's Multiple Range Test (DMRT). (Methodology used as followed by Kalmath, 2002)(3).

\section{Results and Discussion}

\section{Number of seeds per umbel}

The open pollinated plot sprayed with cacambe $(10 \%)$ of water was found significantly superior by recording highest number of seeds/umbel (930.44 seeds/umbel) which resulted in 65.92 and 126.40 per cent increase over open pollination without spray and caged plot without bees, respectively. Further, open pollination sprayed with jaggery $(10 \%)$ of water (913.67 seeds/umbel) which intern recorded 62.93 and 122.31 per cent increases over open pollination without spray and caged plot without spray and caged plot without bees, respectively. The next best treatment was Bee-Q (1.25\%) (728.99 seeds/umbel), cage with bee box (643.53 seeds/umbel). This was followed by open pollination 560.78 (seeds/umbel) and cage without bees (410.98 seeds/umbel) (Table-1). The present findings clearly shows that, application of attractant having positive influence in increasing the number of seeds/umbel which was ultimately due to increased visitation of bees to the umbel resulted in the increased and most efficient cross pollination which resulted in improved quality seed setting.

These findings are in conformity with the results of Sattigi et al. 2001a (5), Guruprasad (2001)(6) they recorded the highest number of seeds/umble in the open pollinated niger crop sprayed with different attractants. Similarly Viraktamath and Patil (1999)(7) and Patil et al.(2000)(8) also recorded higher number of seeds when crop was sprayed with Bee-Q and Bee-here on sesamum. Choudhary and Kumar (1998)(9) also recorded higher percentage of seeds per head $(12.90 \%)$ in open pollinated niger crop compared to control.

\section{Thousand seed weight (test weight)}

The open pollinated crop which received cacambe $(10 \%)$ spray produced significantly and statistically superior test weight (4.19 $\mathrm{g} / 1000$ seeds) with an increase of 90.45 and 98.58 per cent over open pollinated without spray and caged plot without bees, respectively. The treatment with jaggery $(10 \%) \quad(4.10 \mathrm{~g} / 1000$ seeds $)$ and Bee-Q $(1.25 \%)$ (3.85 g/1000 seeds) were equally effectively in recording test weight with an increase of $86.36,75.00$ and $94.31,82.46$ per cent over open pollination without spray and plot caged without bees, respectively. The cage with bee box plot which received was the next best treatment (3.33 g/1000 seeds) followed by open pollination and cage without bees recorded 2.20 and 2.11 g per 1000 seeds, respectively (Table-2). The present results are in line with the reports of Sattigi et al. (2001b)(14) and Guruprasad (2001)(6) on niger, Viraktamath and Patil (1999)(7) on sesamum

\section{Net plot yield}

The open pollinated crop was sprayed with cacambe $(10 \%)$ recorded significantly higher net plot $(4 \mathrm{~m} \mathrm{x} 4 \mathrm{~m})$ yield of $1.42 \mathrm{~kg} / \mathrm{plot}$ which accounted for increase to the tune of 37.86 and 125.40 per cent over open pollinated plot without spray and caged plot without bees, respectively. Same time it was 
on par with open pollinated crop sprayed with jaggery solution (10\%) (1.41 kg/plot), followed by Bee-Q (1.25\%) (1.37 kg/plot) and cage with bee box $(1.15 \mathrm{~kg} / \mathrm{plot})$. The least net plot yield was received in open pollination and cage without bees (1.03 $\mathrm{kg} / \mathrm{plot})$ and $(0.63 \mathrm{~kg} / \mathrm{plot})$, respectively (Table-2).

The converted yield per hectare based on net plot yield followed exactly the same trend in case of net plot yield. Present findings are in agreement with Kumar et al. (1989)(4), Mohan Rao and Suryanarayana (1989)(11), Choudhary and Kumar (1998)(9) and Kulkarni and Dhanorkar (1989)(10), who reported the increased yield in niger due to bee pollination. The present results are in close agreement with the finding of Sattigi et al. (2001b) and Guruprasad (2001)(5\&6) who reported significantly higher seed yield in niger due to application of Bee-Q @ (1.25\%). Similar results of increased seed yield have been reported in sesamum by Viraktamath and Patil (1999)(7).

\section{Influence of bee pollination on qualitative parameters of onion seeds}

\section{Germination percentage}

Significantly higher per cent germination $(92.56 \%)$ was recorded in open pollinated treatment sprayed with cacambe $(10 \%)$ as against 79.34 and 71.08 per cent in the open pollinated without spray and caged plot without bees, respectively, which accounted for 16.67 and 30.22 per cent increase over above two treatments. However, cacambe $(10 \%)$ was on par in recording per cent germination with open pollinated plot sprayed with jaggery (10\%) (89.26\%) and Bee-Q $(1.25 \%)(87.60 \%)$.The cage with bee box recorded 82.64 per cent germination which was the next best treatment with an increase of 4.16 and 16.27 per cent over open pollinated crop without any spray and caged plot without bees, respectively. The per cent germination was minimum with 71.08 in the crop caged without bees which proved significantly inferior to all other treatments (Table.3).

These findings are in agreement with the results of Kumar et al. (1989)(4) who reported highest per cent germination in onion. Patil (1999)(12) also recorded the highest per cent of germination in sesamum crop sprayed with higher dose of Bee-here (3 and $4 \mathrm{ml}$ ) and Bee-Q (1.25 gm/lit). Guruprasad (2001) (6) recorded the highest per cent germination in Niger. In contrast, Sattigi et al (2001b) (5) concluded that bee pollination did not increase the germination per cent in niger. This may due to the changes in the crop phenology and flowering patterns.

Increased germination percentage was obviously attributed to the impact of increased bee visitation on onion crop treated with different attractants both at 5 and 50 per cent flowering. These findings are in line with the results of Kumar et al (1989) (4) who reported the highest per cent germination in onion. Patil (1999)(12) also recorded the highest per cent of germination in sesamum crop sprayed with higher dose of Bee-here (3 and $4 \mathrm{ml}$ ) and Bee-Q (1.25 gm/lit). the present findings also in conformity with the results of Guruprasad (2001)(6). Sattigi et al (2001b)(5) reported that bee pollination did not increase the germination per cent in niger. This may due to the changes in the crop phenology and flowering patterns

\section{Root Length}

Spraying cacambe $(10 \%)$ to open pollinated crop was found significantly superior as it recorded maximum root length of $4.39 \mathrm{~cm}$ which resulted in 33.17 and 44.15 per cent increase over open pollinated without spray and caged plot without bees, respectively. 
Table.1 Influence of bee pollination on quantitative parameters of onion seeds

\begin{tabular}{|c|c|c|c|c|c|c|c|c|c|}
\hline \multirow[t]{2}{*}{ Treatments } & \multirow{2}{*}{$\begin{array}{c}\text { Total no. } \\
\text { Seeds / } \\
\text { umbel }\end{array}$} & \multicolumn{2}{|c|}{$\begin{array}{c}\% \text { increase over } \\
\text { control }\end{array}$} & \multirow{2}{*}{$\begin{array}{l}\text { No. of } \\
\text { chaffy } \\
\text { seeds / } \\
\text { umbel }\end{array}$} & \multicolumn{2}{|c|}{$\begin{array}{c}\% \text { decrease over } \\
\text { control }\end{array}$} & \multirow{2}{*}{$\begin{array}{l}\text { No. of } \\
\text { filled } \\
\text { seeds }\end{array}$} & \multicolumn{2}{|c|}{$\begin{array}{c}\% \text { increase over } \\
\text { control }\end{array}$} \\
\hline & & $\mathbf{O P}$ & caged & & $\mathbf{O P}$ & caged & & OP & caged \\
\hline Cage with bee box (A.cerana) & $643.53^{d}$ & 14.76 & 56.58 & $57.88^{\mathrm{c}}$ & 15.71 & 41.85 & $650.99^{d}$ & 18.68 & 85.94 \\
\hline Cage without bees (Control) & $410.98^{f}$ & - & - & $99.54^{\mathrm{a}}$ & - & - & $350.10^{f}$ & - & - \\
\hline Cacambe $(\mathbf{1 0 \%})$ & $930.44^{\mathrm{a}}$ & 65.92 & 126.40 & $34.75^{\mathrm{t}}$ & 49.40 & 65.09 & $992.55^{\mathrm{a}}$ & 80.95 & 183.50 \\
\hline Bee-Q $(1.25 \%)$ & $728.99^{c}$ & 30.00 & 77.38 & $48.93^{\mathrm{d}}$ & 28.75 & 50.84 & $754.88^{c}$ & 37.62 & 115.62 \\
\hline Jaggery solution (10\%) & $913.67^{b}$ & 62.93 & 122.31 & $42.52^{\mathrm{e}}$ & 38.08 & 57.28 & $965.87^{b}$ & 76.09 & 175.88 \\
\hline Open pollination (OP) & $560.78^{\mathrm{e}}$ & - & 36.45 & $68.67^{b}$ & - & 31.01 & $548.51^{\mathrm{e}}$ & - & 56.67 \\
\hline SEm \pm & 5.19 & & & 1.20 & & & 2.67 & & \\
\hline CD@0.05 & 15.64 & & & 4.70 & & & 8.04 & & \\
\hline
\end{tabular}

Means followed by the same letter in the column do not differ significantly by DMRT (p=-0.05)

Table.2 Influence of bee pollination on quantitative parameters of onion seeds

\begin{tabular}{|c|c|c|c|c|c|c|c|c|c|}
\hline \multirow[t]{2}{*}{ Treatments } & \multirow[t]{2}{*}{$\begin{array}{l}1000 \text { seed } \\
\text { weight }(g)\end{array}$} & \multicolumn{2}{|c|}{$\begin{array}{c}\text { \% increase over } \\
\text { control }\end{array}$} & \multirow{2}{*}{$\begin{array}{l}\text { Net plot } \\
\text { yield } \\
\text { (kg) }\end{array}$} & \multicolumn{2}{|c|}{$\begin{array}{c}\% \text { increase over } \\
\text { control }\end{array}$} & \multirow{2}{*}{$\begin{array}{c}\text { Converted } \\
\text { yield } \\
\text { (kg/ha) }\end{array}$} & \multicolumn{2}{|c|}{$\begin{array}{c}\% \text { increase over } \\
\text { control }\end{array}$} \\
\hline & & OP & caged & & $\mathbf{O P}$ & caged & & $\mathbf{O P}$ & caged \\
\hline Cage with bee box (A.cerana) & $3.33^{\mathrm{d}}$ & 51.36 & 57.82 & $1.15^{\mathrm{c}}$ & 11.65 & 82.54 & $721.56^{\mathrm{d}}$ & 12.26 & 83.08 \\
\hline Cage without bees (Control) & $2.11^{\mathrm{f}}$ & - & - & $0.63^{\mathrm{e}}$ & - & - & $394.13^{\mathrm{f}}$ & - & - \\
\hline Cacambe $(10 \%)$ & $4.19^{\mathrm{a}}$ & 90.45 & 98.58 & $1.42^{\mathrm{a}}$ & 37.86 & 125.40 & $885.28^{\mathrm{a}}$ & 37.74 & 124.62 \\
\hline Bee-Q $(1.25 \%)$ & $3.85^{\mathrm{c}}$ & 75.00 & 82.46 & $1.37^{\mathrm{b}}$ & 33.01 & 117.46 & $854.96^{\mathrm{c}}$ & 33.02 & 116.92 \\
\hline SEm \pm & $\mathbf{0 . 0 3}$ & & & 0.01 & & & 5.62 & & \\
\hline CD@0.05 & 0.08 & & & 0.05 & & & 16.93 & & \\
\hline
\end{tabular}

Means followed by the same letter in the column do not differ significantly by DMRT $(p=-0.05)$ 
Table.3 Influence of bee pollination on qualitative parameters of onion seeds

\begin{tabular}{|c|c|c|c|c|c|c|c|c|c|}
\hline \multirow[t]{3}{*}{ Treatments } & \multirow{3}{*}{$\begin{array}{c}\text { Germination } \\
(\%)\end{array}$} & \multicolumn{2}{|c|}{$\%$ increase over control } & \multicolumn{6}{|c|}{ Seedling vigour } \\
\hline & & & & \multirow{2}{*}{$\begin{array}{l}\text { Root } \\
\text { length } \\
(\mathrm{cm})\end{array}$} & \multicolumn{2}{|c|}{$\begin{array}{c}\% \text { increase over } \\
\text { control }\end{array}$} & \multirow{2}{*}{$\begin{array}{l}\text { Shoot } \\
\text { length } \\
(\mathrm{cm})\end{array}$} & \multicolumn{2}{|c|}{$\begin{array}{c}\% \text { increase over } \\
\text { control }\end{array}$} \\
\hline & & $\mathbf{O P}$ & caged & & OP & caged & & $\mathbf{O P}$ & caged \\
\hline $\begin{array}{l}\text { Cage with bee box } \\
\text { (A.cerana) }\end{array}$ & $82.64^{c}$ & 4.16 & 16.27 & $3.50^{c}$ & 7.08 & 15.91 & $9.09^{c}$ & 15.57 & 27.95 \\
\hline $\begin{array}{l}\text { Cage without bees } \\
\text { (Control) }\end{array}$ & $71.08^{f}$ & - & - & $3.00^{\mathrm{d}}$ & - & - & $7.11^{\mathrm{cd}}$ & - & - \\
\hline Cacambe $(10 \%)$ & $92.56^{\mathrm{a}}$ & 16.66 & 30.22 & $4.39^{\mathrm{a}}$ & 33.17 & 44.15 & $9.92^{\mathrm{a}}$ & 26.09 & 39.60 \\
\hline Bee-Q (1.25\%) & $87.60^{\mathrm{ab}}$ & 10.41 & 23.25 & $4.32^{\mathrm{ab}}$ & 31.10 & 41.91 & $9.79^{a b c}$ & 24.40 & 37.73 \\
\hline Jaggery solution (10\%) & $89.26^{\mathrm{b}}$ & 12.50 & 25.58 & $4.30^{\mathrm{ab}}$ & 32.01 & 42.90 & $9.86^{\mathrm{ab}}$ & 25.25 & 38.66 \\
\hline Open Pollination (OP) & $79.34^{\mathrm{e}}$ & - & 11.62 & $3.23^{\mathrm{b}}$ & - & 8.25 & $7.87^{\mathrm{d}}$ & - & 10.71 \\
\hline SEm \pm & 3.24 & \multirow{2}{*}{\multicolumn{2}{|c|}{ - }} & 0.01 & \multirow{2}{*}{\multicolumn{2}{|c|}{-}} & 1.04 & \multirow{2}{*}{\multicolumn{2}{|c|}{ - }} \\
\hline CD @ 0.05 & 9.74 & & & 0.03 & & & 3.14 & & \\
\hline
\end{tabular}

Means followed by the same letter in the column do not differ significantly by DMRT $(p=-0.05)$ 
However, this treatment was on par with open pollinated treatment with Bee-Q (1.25\%) $(4.32 \mathrm{~cm})$ and jaggery solution $(10 \%)$ $(4.30 \mathrm{~cm})$ in recording the root length. The next best treatment was the cage with bee box (A.cerana) $(3.50 \mathrm{~cm})$ which recorded increased root length of 7.08 and 15.91 per cent over open pollinated crop without spray and caged plot without bees, respectively. This was followed by the treatment of open pollinated crop $(3.23 \mathrm{~cm})$ and caged without bees $(3.00 \mathrm{~cm}$ (Table-3).

The present study endorse the findings of Sattigi et al.(2001b)(5) and Guruprasad (2001)(6) who reported that bee pollination influenced the root length to an extent of 8.34 to $8.69 \mathrm{~cm}$ in niger. Patil et al. (2000) (8) reported that root length was influenced by spraying Bee-Q (12.5 and $15 \mathrm{~g} / \mathrm{l})$ in sesamum

\section{Shoot Length}

Spraying with cacambe (10\%) to open pollinated crop was found significantly superior over other treatments as it recorded maximum shoot length of $9.92 \mathrm{~cm}$ with an increase of 26.09 and 39.60 per cent over pollinated without spray and caged plot without bees, respectively. The next best treatments were jiggery $(10 \%)(9.86 \mathrm{~cm})$ and Bee-Q $(1.25 \%)(9.79 \mathrm{~cm})$. Next to follow was cage with bee box $(9.09 \mathrm{~cm})$ which resulted in an increase of 15.57 and 27.95 per cent over open pollinated without spray and caged plot without bees, respectively than open pollination $(7.87 \mathrm{~cm})$ and cage without bees $(7.11 \mathrm{~cm})($ Table.3).

The present results confirmed the findings of earlier reports on sesamum (Patil, 1999 and Patil et al., 2000) (12,8), Guruprasad (2001)(6) reported that spraying of cinnamon leaf extract, Bee-Q and fruit boost increased the shoot length ranging from $8.41 \mathrm{~cm}$ and $8.79 \mathrm{~cm}$ on niger.
The bee pollination not only increased the yield but also improved the quality of the crop. Such improvements have been reported by some workers. Increase in seedling vigour of safflower due to bee pollination was reported by Lingapppa et al. (1999)(14). Similarly, enhanced in seed weight, diameter and TSS in watermelon were reported by Lingappa et al. (1999)(13) and Sattigi et al. (2001 a and b)(5\&14).

The open pollinated plot sprayed with cacambe $(10 \%)$ of water was found significantly superior by recording highest number of seeds/umbel (930.44 seeds/umbel) which resulted in 65.92 and 126.40 per cent increase over open pollination without spray and caged plot without bees, respectively. Further, open pollination sprayed with jaggery $(10 \%)$ of water (913.67 seeds/umbel) which intern recorded 62.93 and 122.31 per cent increases over open pollination without spray and caged plot without spray and caged plot without bees, respectively. The open pollinated crop sprayed with cacambe $(10 \%)$ recorded significantly higher net plot (4 $\mathrm{m} \mathrm{x} 4$ m) yield of $1.42 \mathrm{~kg} / \mathrm{plot}$ which accounted for increase to the tune of 37.86 and 125.40 per cent over open pollinated plot without spray and caged plot without bees, respectively. treatment sprayed with cacambe (10\%) recorded . Significantly higher per cent germination $(92.56 \%)$, maximum root length of $4.39 \mathrm{~cm}$, maximum shoot length of 9.92 $\mathrm{cm}$. However, this treatment was on par with open pollination with Bee-Q (1.25\%) (4.32 $\mathrm{cm})$ and Jaggery solution $(10 \%)(4.30 \mathrm{~cm})$ in recording the root length. The next best treatments was jaggery $(10 \%)(9.86 \mathrm{~cm})$ and Bee-Q (1.25\%) $(9.79 \mathrm{~cm})$. respectively. Use of attractants to increase the honey bee visits to specific crops would be of great practical value to harvest the benefits of cross pollination. Bee pollination not only increases the yield of various vegetables but also improves its quality. 


\section{References}

1. Kearns C A, Inouye D W and Waser N M 1998. Endangered mutualisms: the conservation of plant-pollinator interactions. Annual Review of Ecology and Systematics 28 (1998): 83-112.

2. Free J B 1993 Insect Pollination of Crops $\left(2^{\text {nd }}\right.$ ed.). San Diego, CA: Academic Press

3. Kalmath, B., 2002, Impact of bee pollination on onion seed production. M.Sc. (Agri.) Thesis, University of Agricultural Sciences, Dharwad.

4. Kumar, J., Mishra, R. C. and Gupta, J. K., 1989, Effect of honey bee pollination on onion (Allium cepa L.) seed production. Indian Bee Journal, 51 : 3-5.

5. Sattigi, H. N., Rajasekhar, D. W. and Kulkarni, K. A., 2001a, Effect of attractants in enhancing the productivity of watermelon. Paper presented at National Symposium on Environment and Evolutionary Biology, Dharwad, 1-3 March, 2001, p. 24.

6. Guruprasad, G. S., 2001, Maximization of Niger productivity through enhancement of bee pollination. M. Sc. (Agri.) Thesis, University of Agricultural Sciences, Dharwad

7. Viraktamath, S. A. and Patil, R.K., 1999, Preliminary studies on the influence of bee attractants on bee visitation and yield parameters of sesamum. Indian Bee Journal, 61: 55-58.

8. Patil, B. S., Viraktamath, S. A., Lingappa, S.,
Giraddi, R. S., Parameshwarappa, K. G., and Bhat, A.R.S., 2000, Effect of Bee-Q and Bee here on pollination and yield of sesamum. Insect Environment, 54: 151-152.

9. Choudhary, O.P. and Kumar, R., 1998, Studies on honey bee foraging behaviour and pollination on niger Guizotia abyssinica Cass. Paper presented at FAO, Workshop on sustainable bee keeping development, Dharwad, 1-5 August 1998.

10. Kumar, R., Chaudhary, D.P. and Lenin, J.K., 1994, Studies on the foraging behavior of honey bees and their role as pollinators of sunflower (Helianthus annuus L.). Indian Bee Journal, 56: 207-2108.

11. Mohan Rao, G. and Suryanarayana, M. C., 1988, Studies on pollination of watermelon (Citrulus lanatus (Thumb.) Mansf.). Indian Bee Journal, 50: 5-8

12. PATIL, B. S., 1999, Role of bee attractants in enhancing productivity and quality of sesamum. M. Sc. (Agri.) Thesis, University of Agricultural Sciences, Dharwad, p, 93.

13. Lingappa, S., Viraktamath, S. A., Vastrad, A. S. and Williams, R., 1999, Utilization of honey bee Apis cerana Fab. for pollination of watermelon and safflower. Proceedings of Apimondia, p. 235.

14. Sattigi, H. N., Rajasekhar, D. W. and Kulkarni, K. A., 2001b, Effect of bee pollination in niger seed production. Paper Presented at National Symposium on Environment and Evolutionary Biology, Dharwad, 1-3 March, 2001, p. 37.

\section{How to cite this article:}

Venkatesh Hosamani, Venkateshalu, N. Jagadeesha, M. S. Reddy, P.M Gangadarappa and B. Ravikumar. 2020. Effect of Bee Pollination and Attractants on Quantitative and Qualitative Parameters of Onion (Alliun cepa) Seed Yield and Quality. Int.J.Curr.Microbiol.App.Sci. 9(02): 1885-1892. doi: https://doi.org/10.20546/ijcmas.2020.902.212 